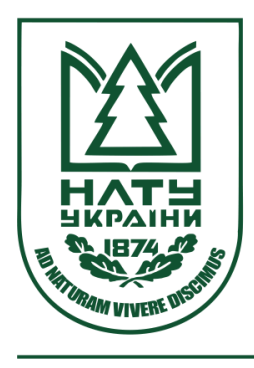

Науковий вісник НлтУ України Scientific Bulletin of UNFU

https://nv.nltu.edu.ua

https://doi.org/10.36930/40310205

$@ \bowtie$ Correspondence author

Article received 15.02.2021 p.

Article accepted 29.04.2021 p.

Yu. V. Zvarych

UDC 630.[165+284]

\title{
ВПЛИВ ПІДСОЧУВАННЯ НА ЖИТТЄВІСТЬ, НАСІННЄНОШЕННЯ ТА МОРФОМЕТРИЧНІ ПОКАЗНИКИ НАСІННЯ СОСНИ ЗВИЧАЙНОЇ НА МАЛОМУ ПОЛІССІ
}

\begin{abstract}
Результати досліджень різних учених не дають однозначного висновку про вплив підсочування дерев сосни на їх життєвість та морфометричні показники насіння. Здійснено дослідження виходу живиці на дослідній ділянці впродовж двох років. Середнє навантаження карами на одне дерево, за середнього діаметра дерев сосни 37,5 см, становило 1,6. Визначено, що середньорічний вихід живиці на одне дерево у перший рік підсочування становив майже 2,5 кг, а у другий - майже 2,3 кг. Досліджено річну динаміку діелектричних показників на дослідній та контрольній ділянках упродовж двох років підсочування. Встановлено, що перед початком підсочування імпеданс та поляризаційна ємність дерев на обох ділянках були майже однакові. Виявлено, що на початку сезону підсочування життєвість підсочених дерев зменшується, порівняно із контролем. У другій половині сезонного підсочування показники життєвості починають вирівнюватись і після іiі завершення стають практично однаковими на обох ділянках. Визначено, за методикою Каппера, насіннєношення модельних дерев на дослідній ділянці - "середнє", а на контрольній - "середнє-сильне". Встановлено, що за довжиною шишок зразки із дослідних ділянок перевищують контрольні на 1,5-2,5 мм. Діаметр шишок також є більшим на дослідних ділянках на 0,9-1,2 мм. Відповідно і маса шишок на дослідних ділянках перевищує контрольні на 0,6-0,8 г. Панівною формою шишок на усіх пробних площах є конусоподібна. Визначено, що найбільший показник довжини насіння спостерігається на дослідній ділянці ВМ-9РП (4,37 мм), а найменший - на дослідній ділянці ВМ-2 (4,12 мм). Ширина насіння є однаковою. Маса насіння $€$ найменшою на дослідній ділянці ВМ-2 (5,7 мг), а найбільшою - на дослідній ділянці ВМ-9РП (6,8 мг). Загалом проведені дослідження свідчать про зниження життєвості дерев сосни на початку сезону підсочування на дослідних ділянках і вирівнювання відповідних показників у другій ії половині. Морфометричні показники шишок дослідних ділянок $є$ більшими, ніж контрольних, а насіння практично однаковими.
\end{abstract}

Ключові слова: смолопродуктивність; імпеданс; поляризаційна ємність; шишки; насіння.

\section{Вступ}

Одним із недеревних продуктів лісу є живиця, яку добувають із дерев сосни під час проведення їх підсочування. Тому дослідники вивчали іiі вплив на життєвість дерев, їх плодоношення та якість насіння. Аналіз літературних даних про вплив підсочування на насіннєношення сосни звичайної є неоднорідним. Одні джерела [2, 4] свідчать про відсутність негативного впливу підсочування, інші [1, 3, 11, 19] - навпаки. Різняться думки вчених і щодо впливу підсочування на морфометричні показники шишок і насіння запідсочених дерев. Деякі вчені $[2,4]$ стверджують, що підсочування не має впливу на ці показники, інші $[1,7,11,15]$ відзначають, що у підсочених дерев зменшуються розміри і шишок, і насіння. У своїх працях деякі вчені наголошують на тому, що підсочування не має істотного впливу на посівні якості насіння [3, 5, 7, 15, 19]. Інші вчені [14] за результатами своїх досліджень відзначають збільшення маси і покращення посівних якостей насіння.

Електрофізіологічні показники (імпеданс та поляри- заційна ємність), певною мірою, відображають інтенсивність і особливості перебігу фізіолого-біохімічних процесів та характеризують загальний стан рослин, їх життєвість $[13,14]$. Вплив підсочування на життєвість дерев сосни звичайної $\epsilon$ неоднорічним. За даними В. П. Галушки [5], підсочені дерева сосни звичайної відзначаються меншою життєвістю від контрольних упродовж усього року. За даними Л. С. Осадчука [17], у перші роки підсочування дослідні дерева відзначаються кращою життєвістю порівняно із контрольними.

Вивчення цього питання є актуальним у галузі лісового господарства. Адже підсочування може мати як позитивний, так і негативний вплив на насіння дерев сосни звичайної, його якісні та кількісні характеристики і його використання у лісовому господарстві, а також на життєвість дерев і здатність їх росту та розвитку після закінчення підсочувальних робіт.

Об'єкт дослідження - стиглі деревостани сосни звичайної (склад 10С3+Бп; бонітет I; тип лісу $\mathrm{B}_{2}$-дС - свіжий дубово-сосновий субір) Великомістівського лісництва ДП "Жовківське лісове господарство". Контрольна ділянка ВМ-1 та дослідні ділянки ВМ-2, де під-

Інформація про авторів:

Зварич Юрій Володимирович, асистент, кафедра лісівництва. Email: yurazvarych@gmail.com

Зварич Олена Дмитрівна, викладач. Email: olenazvarych76@gmail.com

Цитування за ДСту: Зварич Ю. В., Зварич О. Д. Вплив підсочування на життєвість, насіннєношення та морфометричні показники насіння сосни звичайної на Малому Поліссі. Науковий вісник НЛтУ України. 2021, т. 31, № 2. С. 35-39.

Citation APA: Yu. V. Zvarych, \& Zvarych, O. D. (2021). Influence of tapping on vitality, production and morphometric indicators of Scots Pine seeds in Small Polissya. Scientific Bulletin of UNFU, 31(2), 35-39. https://doi.org/10.36930/40310205 
сочування проводили впродовж одного року, та ВМ9РП, ділянка, на якій шість років тому завершився дев'ятирічний термін підсочування.

Предмет дослідження - методи та засоби для визначення життєвості та насіннєношення дерев сосни звичайної для визначення впливу процедури підсочування на ці показники.

Мета роботи - визначити вплив підсочування на діелектричні показники та насіннєношення дерев сосни звичайної.

Для досягнення зазначеної мети визначено такі основні завдання дослідження:

- встановити смолопродуктивність підсочених дерев;

- визначити показники насіннєношення модельних дерев на підсочених та контрольних ділянках;

- виконати заміри річної динаміки діелектричних показників на підсочених та контрольних ділянках.

Наукова новизна отриманих результатів дослідження - вперше визначено річну динаміку діелектричних показників підсочених та контрольних ділянок сосни звичайної. Морфометричні показники шишок і насіння сосни звичайної визначали на контрольній ділянці, дослідній ділянці з однорічним терміном підсочування та дослідній ділянці, де підсочування проводили впродовж 9 років і закінчилось 6 років до проведення досліджень.

Практична значущість результатів дослідження результати дослідження можуть бути використані для визначення доцільності використання якісного насіння сосни звичайної із підсочених дерев.

Аналіз останніх досліджень та публікацій. За даними багатьох дослідників одними із головних показників для дослідження життєвості деревних рослин $є$ імпеданс та поляризаційна ємність [8, 10, 12, 13, 20].

Вплив підсочування на електрофізіологічні показники досліджувало багато вчених $[5,11,15,16,18]$. Так, за даними В. П. Галушки [5], величина імпедансу у дослідних насаджень у період спокою (грудень - лютий) на 16-56 \% перевищує контроль, а в період вегетації (квітень - серпень) - на 11,3-22,8 \%. За даними цього ж дослідника величина поляризаційної ємності як у період спокою, так і в період вегетації у дослідних варіантів була значно нижчою, ніж у контрольних [5]. За даними Л. С. Осадчука [16], показник імпедансу спадає, а поляризаційної ємності зростає у перші роки підсочування, що свідчить про вищу активність фізіологічних процесів дослідних дерев порівняно із контрольними. За даними I. В. Рутковського [18], після нанесення підновок поглиблюються відмінності за величиною поляризаційної ємності між дослідними та контрольними деревами, а відмінності між ослабленими та здоровими деревами зникають.

Вплив підсочування дерев сосни звичайної на розміри шишок і насіння вивчали дослідники $[1,2,3,4,5,6$,
7, 11, 14, 17, 19]. Так, Я. Г. Дрочнєв [2] стверджує, що під впливом підсочування розміри шишок і насіння не змінюються, а саме насіння дещо відрізняється за своїми кількісними і якісними показниками від насіння непідсочуваних дерев. За даними М. А. Сгоренкова та Ф. А. Мєднікова [4] розміри шишок і насіння, а також схожість насіння майже не змінюються або мало змінюються. Ю. С. Биченко [1], Я. Н. Лубяко та І. Д. Юркевич [14], І. А. Яхонтов [7] у своїх працях також наголошують на тому, що підсочування не має істотного впливу на посівні якості насіння.

Водночас, інші дослідники: В. П. Галушка [6], Я. Г. Дрочнєв, Н. М. Вишневская, Т. Б. Худеньких [3] стверджують, що параметри шишок і насіння підсочуваних дерев $\epsilon$ меншими, порівняно із контролем. Ю. С. Биченко [1], Н. М. Воронов [19], І. А. Яхонтов [7] також стверджують, що підсочування впливає на зменшення параметрів шишок. Н. М. Воронов [19] також виявив, що від тривалості підсочування залежить і кількість сформованого пустого насіння.

Водночас, Е. Г. Парамонов [17] за результатами своїх досліджень відзначає збільшення маси і покращення посівних якостей насіння.

Матеріали та методи дослідження. Вимірювання поляризаційної ємності та імпедансу лубу стовбурів дослідних і контрольних дерев виконували за допомогою приладу Ф 4320 за частоти 1 кГц $[5,13]$. Електроди вводили в луб стовбурів на висоті 1,3 м. Відстань між електродами становила 2 см. Вимірювання цих показників виконували у суху сонячну погоду впродовж світлового дня. Урожайність дерев визначали окомірним способом за методикою Каппера [9].

Вихід живиці визначали впродовж сезону підсочування після нанесення семи підновок на кожній карі дерева і наповнення смолоприймачів. Для кожного дерева визначали масу порожнього смолоприймача перед початком підсочування і відповідну його масу після наповнення його живицею. Після закінчення сезону підсочування визначали загальну масу виходу живиці для кожного дерева.

\section{Результати дослідження та їх обговорення}

На дослідній ділянці (ВМ-2) ми вивчали смолопродуктивність окремих дерев впродовж двох років. Середнє навантаження карами на одне дерево, за середнього діаметра дерев сосни 37,5 см, становило 1,6. Загалом за перший рік підсочування із 172 дерев сосни було зібрано майже 429 кг живиці, а у 2004 р. із 168 дерев (4 дерева за період до початку підсочування всохло) - майже 382 кг (табл. 1). Якщо порівнювати середньорічний вихід живиці на одне дерево, то можна зазначити, що у 2003 р. він становив майже 2,5 кг, а у 2004 р. - майже 2,3 кг.

Табл. 1. Вихід живиці на дослідній пробній площі

\begin{tabular}{|c|c|c|c|c|c|}
\hline Дата & Маса живиці, г & Вихід живиці на 1 дерево, г & Дата & Маса живиці, г & Вихід живиці на 1 дерево, г \\
\hline 06.06 .2003 & 72505 & $422^{ \pm 5,9}$ & 31.05 .2004 & 107350 & $639^{ \pm 22,3}$ \\
\hline 09.07 .2003 & 106965 & $622^{ \pm 22,0}$ & 25.06 .2004 & 129775 & $772^{ \pm 26,2}$ \\
\hline 28.07 .2003 & 82635 & $480^{ \pm 17,3}$ & 16.07 .2004 & 53740 & $320^{ \pm 1,8}$ \\
\hline 20.08 .2003 & 69715 & $405^{ \pm 16,0}$ & 20.09 .2004 & 90825 & $541^{ \pm 20,8}$ \\
\hline 01.11 .2003 & 96955 & $564^{ \pm 21,4}$ & & & $2272^{ \pm 78,1}$ \\
\hline Разом за рік & 428775 & $2493^{ \pm 89,7}$ & Разом за рік & 381690 & \\
\hline
\end{tabular}

Упродовж двох років (2003-2004 рр.) на пробних площах практично щомісячно виконували заміри імпе- дансу та поляризаційної ємності лубу підсочених та контрольних дерев сосни звичайної (рис. 1, 2; табл. 2, 3). 


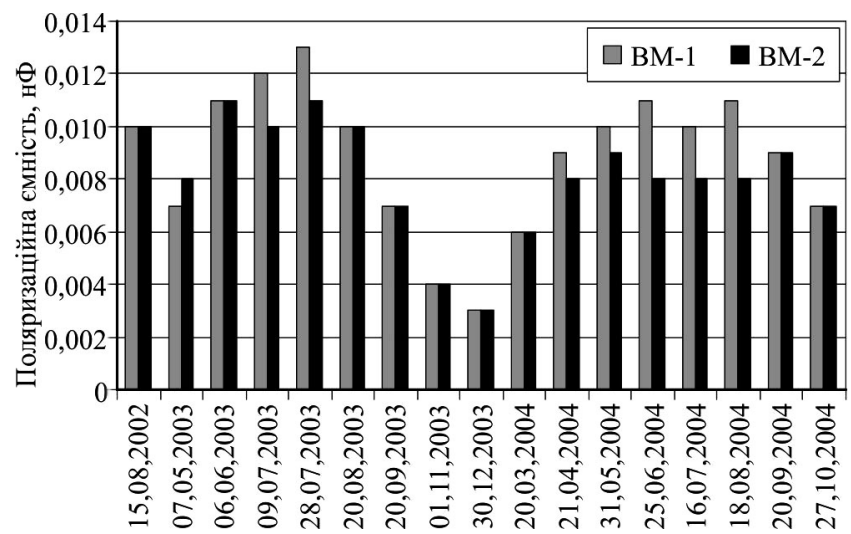

Згідно з даними рис. 1, поляризаційна ємність у річному розрізі починає збільшувати свої показники з початку року і досягає найбільших показників у літній період (червень - серпень). Після цього іії показники починають зменшуватись. Із імпедансом ми спостерігаємо зворотній процес (див. рис. 2): найбільші його показники зафіксовано в зимовий період, а найменші - у літній (червень - серпень). Такі дані свідчать про зростання біологічної активності дерев сосни, пік якої припадає саме на літні місяці. Аналізуючи зміни поляризаційної ємності у контрольних і дослідних дерев (див. рис. 1, табл. 2), з'ясували, що за рік до початку підсочування цей показник на обох пробних площах був однаковим.

Рис. 1. Поляризаційна ємність дослідної та контрольної ділянок

Табл. 2. Середнє значення поляризаційної ємності лубу сосни звичайної на контрольній та дослідній ділянках

\begin{tabular}{|c|c|c|c|c|c|c|c|c|}
\hline \multirow[t]{2}{*}{ Дата } & \multicolumn{2}{|c|}{ Контроль (ВМ-1) } & \multicolumn{2}{|c|}{$\begin{array}{l}\text { Відносно середнього } \\
\text { значення контролю }\end{array}$} & \multicolumn{2}{|c|}{ Дослід (BM-2) } & \multicolumn{2}{|c|}{ Відносно контролю } \\
\hline & $M^{ \pm m}$ & $V, \%$ & $\%$ & $t_{\phi}$ & $M^{ \pm m}$ & $V, \%$ & $\%$ & $t_{\phi}$ \\
\hline 15.08 .02 & $0,010^{ \pm 0,0002}$ & 23,42 & 111,11 & 1,37 & $0,010^{ \pm 0,0002}$ & 23,56 & 100,00 & 0,00 \\
\hline 07.05 .03 & $0,007^{ \pm 0,0002}$ & 23,69 & 77,78 & $-2,75$ & $0,008^{ \pm 0,0001}$ & 22,32 & 114,29 & 4,47 \\
\hline 06.06 .03 & $0,011^{ \pm 0,0002}$ & 22,69 & 122,22 & 2,75 & $0,011^{ \pm 0,0002}$ & 22,49 & 100,00 & 0,00 \\
\hline 09.07 .03 & $0,012^{ \pm 0,0003}$ & 22,96 & 133,33 & 3,94 & $0,008^{ \pm 0,0002}$ & 29,81 & 66,67 & $-11,09$ \\
\hline 28.07 .03 & $0,013^{ \pm 0,0003}$ & 21,64 & 144,44 & 5,25 & $0,010^{ \pm 0,0002}$ & 24,84 & 76,92 & $-8,32$ \\
\hline 20.08 .03 & $0,010^{ \pm 0,0003}$ & 24,65 & 111,11 & 1,31 & $0,010^{ \pm 0,0004}$ & 53,44 & 100,00 & 0,00 \\
\hline 20.09 .03 & $0,007^{ \pm 0,0002}$ & 26,65 & 77,78 & $-2,75$ & $0,007^{ \pm 0,0004}$ & 77,24 & 100,00 & 0,00 \\
\hline 01.11 .03 & $0,004^{ \pm 0,0001}$ & 27,75 & 44,44 & $-4,10$ & $0,004^{ \pm 0,0001}$ & 33,89 & 100,00 & 0,00 \\
\hline 30.12 .03 & $0,003^{ \pm 0,0001}$ & 23,79 & 33,33 & $-8,49$ & $0,003^{ \pm 0,0001}$ & 25,89 & 100,00 & 0,00 \\
\hline 20.03 .04 & $0,006^{ \pm 0,0005}$ & 71,33 & 66,67 & $-3,49$ & $0,006^{ \pm 0,0001}$ & 21,89 & 100,00 & 0,00 \\
\hline 21.04 .04 & $0,009^{ \pm 0,0002}$ & 19,35 & 100,00 & 0,00 & $0,008^{ \pm 0,0001}$ & 23,06 & 88,89 & $-4,47$ \\
\hline 31.05 .04 & $0,010^{ \pm 0,0002}$ & 21,64 & 111,11 & 1,37 & $0,010^{ \pm 0,0005}$ & 68,76 & 100,00 & 0,00 \\
\hline 25.06 .04 & $0,011^{ \pm 0,0003}$ & 24,06 & 122,22 & 2,63 & $0,008^{ \pm 0,0002}$ & 25,80 & 72,73 & $-10,61$ \\
\hline 16.07 .04 & $0,010^{ \pm 0,0002}$ & 21,05 & 111,11 & 1,37 & $0,008^{ \pm 0,0002}$ & 25,89 & 80,00 & $-7,07$ \\
\hline 18.08 .04 & $0,011^{ \pm 0,0002}$ & 21,24 & 122,22 & 2,75 & $0,008^{ \pm 0,0002}$ & 23,78 & 72,73 & $-10,61$ \\
\hline 20.09 .04 & $0,009^{ \pm 0,0002}$ & 21,33 & 100,00 & 0,00 & $0,009^{ \pm 0,0002}$ & 24,46 & 100,00 & 0,00 \\
\hline 27.10 .04 & $0,007^{ \pm 0,0002}$ & 23,40 & 77,78 & $-2,75$ & $0,007^{ \pm 0,0001}$ & 26,16 & 100,00 & 0,00 \\
\hline Середнє & $0,009^{ \pm 0,0007}$ & 31,36 & 100,00 & & $0,008^{ \pm 0,0005}$ & 26,89 & 88,89 & $-1,16$ \\
\hline
\end{tabular}

Примітка: теоретичне значення критерію Ст'юдента $\left(t_{05}\right)$ для ПП ВМ-1 дорівнює 1,9840, для ПП ВМ-9РП - 1,9739.

У перший рік підсочування (2003 р.) у травні та на початку червня показники $є$ практично однаковими. Вже у липні зафіксовано істотне перевищення показника контрольної ділянки над дослідною на 23-33 \%. Це можна пояснити фізіологічною реакцією дерев на механічні пошкодження їх підновками, що призводить до виділення смоли. Із серпня 2003 по березень 2004 рр. цей показник був однаковий на обох ділянках. На початок вегетаційного періоду 2004 р. (квітень) цей показник на дослідній ділянці менший від контрольної на 12,5 \%. Упродовж другого року підсочування 3 червня по серпень спостерігаємо переважання показника поляризаційної ємності на контрольній ділянці над дослідною на 20,0-27,3\%. Після чого у вересні - жовтні 2004 р. показники знову вирівнюються на обох ділянках. Аналогічні результати відображено у досліджен- нях В. П. Галушки [5]. А дослідження, проведені Л. С. Осадчуком [16], показують, що показники поляризаційної ємності є більшими у дослідних варіантів.

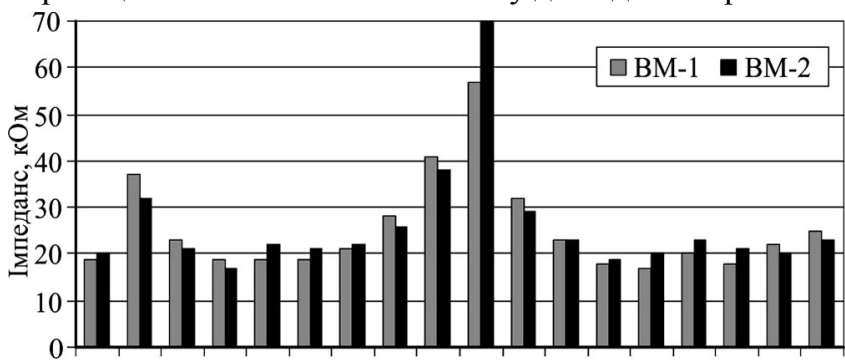

రิં

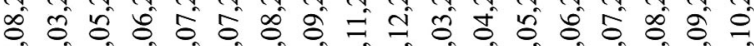

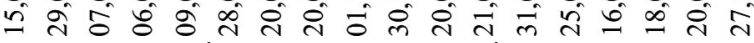

Рис. 2. Імпеданс дослідної та контрольної ділянок

Табл. 3. Середнс значення імпедансу лубу сосни звичайної на контрольній і дослідній ділянках

\begin{tabular}{|c|c|c|c|c|c|c|c|c|}
\hline \multirow{2}{*}{ Дата } & \multicolumn{2}{|c|}{ Контроль (ВМ-1) } & \multicolumn{2}{|c|}{$\begin{array}{c}\text { Відносно середнього } \\
\text { значення контролю }\end{array}$} & \multicolumn{2}{|c|}{ Дослід (ВМ-2) } & \multicolumn{2}{|c|}{ Відносно контролю } \\
\cline { 2 - 9 } & $M^{ \pm m}$ & $V, \%$ & $\%$ & $t_{\phi}$ & $M^{ \pm m}$ & $V, \%$ & $\%$ & $t_{\phi}$ \\
\hline 1 & 2 & 3 & 4 & 5 & 6 & 7 & 8 & 9 \\
\hline 15.08 .02 & $20^{ \pm 0,5866}$ & 30,01 & 78,13 & $-2,17$ & $20^{ \pm 0,3950}$ & 25,79 & 100,00 & 0,00 \\
\hline 29.03 .03 & $36^{ \pm 1,3751}$ & 38,70 & 140,63 & 3,63 & $31^{ \pm 0,6965}$ & 27,15 & 86,11 & $-3,24$ \\
\hline 07.05 .03 & $23^{ \pm 0,5824}$ & 25,83 & 89,84 & $-1,01$ & $21^{ \pm 0,3712}$ & 23,05 & 91,30 & $-2,90$ \\
\hline 06.06 .03 & $19^{ \pm 0,6655}$ & 35,20 & 74,22 & $-2,56$ & $18^{ \pm 0,3449}$ & 25,97 & 94,74 & $-1,33$ \\
\hline 09.07 .03 & $19^{ \pm 0,5934}$ & 31,47 & 74,22 & $-2,54$ & $23^{ \pm 0,4469}$ & 26,01 & 121,05 & 5,38 \\
\hline 28.07 .03 & $20^{ \pm 0,7018}$ & 35,59 & 78,13 & $-2,15$ & $21^{ \pm 0,3839}$ & 23,82 & 105,00 & 1,25 \\
\hline
\end{tabular}




\begin{tabular}{|c|c|c|c|c|c|c|c|c|}
\hline 1 & 2 & 3 & 4 & 5 & 6 & 7 & 8 & 9 \\
\hline 20.08 .03 & $21^{ \pm 0,6034}$ & 28,34 & 82,03 & $-1,78$ & $23^{ \pm 0,4037}$ & 23,53 & 109,52 & 2,75 \\
\hline 20.09 .03 & $28^{ \pm 0,6166}$ & 21,77 & 109,38 & 0,93 & $26^{ \pm 0,4393}$ & 22,20 & 92,86 & $-2,64$ \\
\hline 01.11 .03 & $41^{ \pm 1,2513}$ & 30,61 & 160,16 & 5,49 & $38^{ \pm 0,7121}$ & 24,73 & 92,68 & $-2,08$ \\
\hline 30.12 .03 & $59^{ \pm 2,0694}$ & 35,08 & 230,67 & 10,27 & $70^{ \pm 1,4013}$ & 26,18 & 118,64 & 4,40 \\
\hline 20.03 .04 & $32^{ \pm 0,7459}$ & 23,47 & 125,00 & 2,45 & $29^{ \pm 0,4792}$ & 21,52 & 90,63 & $-3,38$ \\
\hline 21.04 .04 & $23^{ \pm 0,5032}$ & 21,91 & 89,84 & $-1,02$ & $23^{ \pm 0,3616}$ & 20,56 & 100,00 & 0,00 \\
\hline 31.05 .04 & $19^{ \pm 0,4959}$ & 27,05 & 74,22 & $-2,58$ & $19^{ \pm 0,3368}$ & 23,22 & 100,00 & 0,00 \\
\hline 25.06 .04 & $17^{ \pm 0,4629}$ & 27,30 & 66,41 & $-3,37$ & $20^{ \pm 0,3485}$ & 22,70 & 117,65 & 5,18 \\
\hline 16.07 .04 & $20^{ \pm 0,5419}$ & 26,56 & 78,13 & $-2,18$ & $24^{ \pm 0,4391}$ & 24,18 & 120,00 & 5,74 \\
\hline 18.08 .04 & $18^{ \pm 0,5117}$ & 28,34 & 70,31 & $-2,97$ & $21^{ \pm 0,3805}$ & 23,75 & 116,67 & 4,70 \\
\hline 20.09 .04 & $22^{ \pm 0,5857}$ & 26,17 & 85,94 & $-1,40$ & $21^{ \pm 0,3698}$ & 23,26 & 95,45 & $-1,44$ \\
\hline 27.10 .04 & $25^{ \pm 0,6799}$ & 26,42 & 97,66 & $-0,23$ & $23^{ \pm 0,4419}$ & 24,54 & 92,00 & $-2,47$ \\
\hline Середнс & $25,6^{ \pm 2,5090}$ & 41,56 & 100,00 & & $26,2^{ \pm 2,8229}$ & 45,77 & 102,34 & 0,16 \\
\hline
\end{tabular}

Примітка: теоретичне значення критерію Ст'юдента $\left(t_{05}\right)$ для ПП ВМ-1 дорівнює 1,9840, для ПП ВМ-9РП - 1,9739.

Аналізуючи показники імпедансу на цих же пробних площах (див. табл. 3), спостерігаємо зворотній до попереднього процес. За рік до початку підсочування показники імпедансу на обох пробах були однакові. Після початку проведення підсочування цей показник на дослідній вищий від контрольної на 4,7-17,3 \%, а піс-

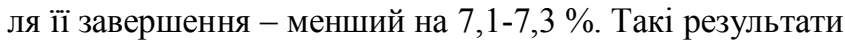
відповідають результатам досліджень В. П. Галушки [5], які вказують, що імпеданс дослідних варіантів перевищує контрольні. А дані досліджень Л. С. Осадчука [16] свідчать, що показники імпедансу контрольних варіантів перевищують дослідні.

Дослідження зміни електрофізіологічних показників свідчить про зменшення життєвості підсочених дерев у період проведення підсочування та покращення іï у дослідних дерев після закінчення періоду досліджень.

Дослідження урожайності дерев сосни проводили у березні 2003 р. Аналізуючи дані 3 плодоношення модельних дерев, можна зазначити, що на ПП ВМ-9РП у дерев спостерігається переважно "середнє" насіннєношення. На пробній площі BM-1 у модельних дерев спостерігається переважно "середнє-сильне" насіннєношення, що $€$ найкращим показником серед досліджуваних ділянок.

Табл. 4. Морфометричні показники шишок модельних дерев, 2003 p.

\begin{tabular}{|c|c|c|c|c|c|c|}
\hline \multirow{2}{*}{$\begin{array}{c}\text { Варіант } \\
\text { досліду }\end{array}$} & \multicolumn{2}{|c|}{ Довжина, мм } & \multicolumn{2}{c|}{ Діаметр, мм } & \multicolumn{2}{|c|}{ Маса, Г } \\
\cline { 2 - 7 } & $M^{ \pm m}$ & $V, \%$ & $M^{ \pm m}$ & $V, \%$ & $M^{ \pm m}$ & $V, \%$ \\
\hline ВМ-2 & $38,2^{ \pm 0,24}$ & 10,1 & $18,0^{ \pm 0,11}$ & 9,9 & $5,0^{ \pm 0,09}$ & 27,5 \\
\hline ВМ-9РП & $37,5^{ \pm 0,19}$ & 10,4 & $18,2^{ \pm 0,09}$ & 9,8 & $5,2^{ \pm 0,07}$ & 25,4 \\
\hline ВM-1 & $35,9^{ \pm 0,19}$ & 15,0 & $17,1^{ \pm 0,08}$ & 13,4 & $4,4^{ \pm 0,06}$ & 37,9 \\
\hline
\end{tabular}

На підставі досліджень біометричних показників шишок сосни звичайної (табл. 4) констатуємо, що за довжиною шишок дослідні зразки (ВМ-2 та ВМ-9РП) перевищують контроль (ВМ-1) на 4,2-6,0%. Найбільший цей показник у дослідних зразків після однорічного підсочування. Щодо діаметра шишок, то за цим показником випереджають всіх зразки, зібрані на ділянці ВМ-9РП. Знову ж таки, найменший цей показник спостерігаємо на контрольній ділянці. Він відрізняється від дослідних варіантів на 5,0-6,0 \%. Маса шишок на дослідних ділянка перевищує масу шишок на контрольній на 12,0-15,3 \%. Дослідження інших учених мають суперечливий характер. Так, за даними Ю. С. Биченко [1], Н. М. Воронова [19] та В. П. Галушки [6], морфометричні показники шишок підсочуваних дерев $є$ значно меншими, ніж у контрольних. За даними досліджень А. С. Коростелева, С. В. Залесова, Г. А. Годовалова [11], довготермінове підсочування знижує масу шишок запідсочених дерев на 6-35 \%, довжину - на 3$22 \%$ і діаметр - на 2-15\%. 3 іншого боку, багаторічні спостереження Я. Г. Дрочнєва [2] не виявили впливу підсочування на розміри і кількість насіння та біометричні показники шишок.

Панівною формою шишок на усіх пробних площах $€$ конусоподібна. Тільки на деяких модельних деревах пробних площ ВМ-2 та ВМ-9РП трапляється значний відсоток шишок із конусоподібнозагнутою формою.

Табл. 5. Морфометричні показники насіння модельних дерев, 2003 р.

\begin{tabular}{|c|c|c|c|c|c|c|}
\hline \multirow{2}{*}{$\begin{array}{c}\text { Варіант } \\
\text { досліду }\end{array}$} & \multicolumn{2}{|c|}{ Довжина, мм } & \multicolumn{2}{|c|}{ Ширина, мм } & \multicolumn{2}{c|}{ Маса, мг } \\
\cline { 2 - 7 } & $M^{ \pm m}$ & $V, \%$ & $M^{ \pm m}$ & $V, \%$ & $M^{ \pm m}$ & $V, \%$ \\
\hline ВМ-2 & $4,1^{ \pm 0,02}$ & 8,1 & $2,4^{ \pm 0,01}$ & 7,7 & $5,7^{ \pm 0,10}$ & 24,7 \\
\hline ВМ-9РП & $4,4^{ \pm 0,02}$ & 6,2 & $2,4^{ \pm 0,01}$ & 8,4 & $6,8^{ \pm 0,06}$ & 13,3 \\
\hline ВМ-1 & $4,3^{ \pm 0,01}$ & 8,1 & $2,4^{ \pm 0,01}$ & 8,4 & $5,9^{ \pm 0,05}$ & 20,6 \\
\hline
\end{tabular}

Дослідження біометричних показників насіння модельних дерев сосни звичайної (табл. 5) показують, що найбільший показник довжини насіння $€$ на ділянці ВМ-9РП і становить 4,4 мм, що на 2,3\% більше від контролю, а найменший - на ВМ-2-4,1 мм, що на 4,7 \% менше від контролю. Ширина насіння є однаковою. Маса насіння є найменшою у ВМ-2 і становить 5,7 мг, що на 3,4 \% є менше від контролю, а найбільшою на ВМ-9РП - 6,8 мг, що на 13,2 \% більше від контролю. А отже, не можна відзначити істотної відмінності між морфометричними показниками насіння контрольних i дослідних дерев. Аналогічні показники отримано внаслідок досліджень Я. Г. Дрочнєва [2]. Хоча інші дослідники $[1,6,19]$ вказують на менші морфометричні показники насіння підсочених дерев порівняно 3 контрольними.

\section{Висновки}

Результати проведених досліджень свідчать про те, що на початку проведення підсочування щороку знижується життєвість підсочених дерев відносно контрольних. Наприкінці періоду підсочування (серпень вересень) й у зимовий період життєвість дослідних і контрольних дерев практично однакові за електрофізіологічними показниками. Морфометричні показники шишок дерев на дослідних ділянках є більшими, ніж на контрольній. Істотної різниці між морфометричними показниками насіння дослідних і контрольних варіантів не виявлено.

\section{References}

1. Bychenko, Iu. S. (1935). Vliianie podsochki na prirost, fizikomekhanicheskie i fiziologicheskie svoistva sosny. Lesokhimicheskaia promishlennost, 1, 9-18. [In Russian]. 
2. Drochnev, Ia. G. (1979). Biologicheskie osnovy tekhnologii podsochki. Moscow: Lesnaia promshlennost. [In Russian].

3. Drochnev, Ia. G., Vishnevskaia, N. M., \& Khudenkikh, T. B. (1978). Vliianie mnogoletnei podsochki na semenoshenie sosny. Lesnoe khoziaistvo, 2, 34-35. [In Russian].

4. Egorenkov, M. A., \& Mednikov, F. A. (1983). Podsochka lesa. Minsk: Vysheishaia shkola. [In Russian].

5. Halushka, V. P. (1999). Dielektrychna reaktsiia sosny zvychainoi na pidsochku. Tezy mizhnarodnoi naukovo-praktychnoi konferentsii "Problemy ta perspektyvy rozvytku lisivnychoi osvity, nauky ta vyrobnytstva" (14-16 kvitnia 1999 year). Lviv: UkrDLTU, 27-28. [In Ukrainian].

6. Halushka, V. P. (1999). Vplyv pidsochuvannia na morfometrychni pokaznyky nasinnia i shyshok sosny zvychainoi. Scientific Bulletin of UkrSFU, 9(8), 23-28. [In Ukrainian].

7. Iakhontov, I. A. (1931). Opyty podsochki sosny i vyiasneniia ee vliianiia na prirost, plodonoshenie i tekhnicheskie svoistva podsachivaemogo dereva. Seriia nauchnykh izdanii Ukrainskogo NIILKh. Kharkov: Goslestekhizdat, 6. [In Russian].

8. Kaleniuk, Yu. S., \& Zaika, V. K. (2019). Bioelektrychni potentsialy duba i lypy v derevostanakh svizhoi hrabovoi dibrovy Zakhidnoho Podillia. Scientific Bulletin of UNFU, 29(1), 49-53. https://doi.org/10.15421/40290110

9. Kapper, O. G. (1938). Khvoinye porody. Moscow: Selkhozgiz. [In Russian].

10. Kerimov, E. I., \& Zaika, V. K. (2018). Dielektrychni pokaznyky derevnykh vydiv u derevostanakh za uchastiu Modryny Yevropeiskoi. Scientific Bulletin of UNFU, 28(8), 23-27. https://doi.org/10.15421/40280804

11. Korostelev, A. S., Zalesov, S. V., \& Hodovalov, H. A. (2010). Nedrevesnaia produktsyia lesa: uchebnyk. Ekaterynburh: Uralskyi hosudarstvennyi lesotekhnycheskyi unyversytet. [In Russian].
12. Kratiuk, O. L. (2020). Dielektrychni pokaznyky sosny zvychainoi $\mathrm{v}$ umovakh napivvilnoho utrymannia ratychnykh (cervidae, bovidae) na terytorii Zakhidnoho i Tsentralnoho Polissia. Scientific Bulletin of UNFU, 30(1), 55-59. https://doi.org/10.36930/40300109

13. Krynytskyi, H. T. (1992). Pro metodyku vykorystannia elektrofiziolohichnykh pokaznykiv dlia vyznachennia zhyttiezdatnosti derevnykh roslyn. Lisove hospodarstvo, lisova, paperova i derevoobrobna promyslovist, 23, 3-10. [In Ukrainian].

14. Lubiako, M. N., \& Iurkevich, I. D. (1940). Vliianie podsochki na plodonoshenie. Lesnoe khoziaistvo, 1, 17-21. [In Russian].

15. Maksym, Ya. V. (1996). Vplyv parametrychnoi budovy derev na smoloproduktyvnist sosny zvychainoi v umovakh Maloho Polissia. Abstract of Candidate Dissertation for Agricultural Sciences (06.00.20 - lisoznavstvo i lisivnytstvo, Ukrainskyi derzhavnyi lisotekhnichnyi universytet, Lviv, Ukraina). [In Ukrainian].

16. Osadchuk, L. S. (2000). Otsinka zhyttiediialnosti zapidsochenykh nasadzhen sosny zvychainoi v umovakh Maloho Polissia. . Scientific herald of the National Agrarian University. Series: Forestry, 27, 131-137. [In Ukrainian].

17. Paramonov, E. G. (1983). Vliianie podsochki na zhiznedeiatelnost nasazhdenii. Moscow: Lesnaia promishlennost. [In Russian].

18. Rutkovskii, I. V., Popivshhii, I. I., \& Kabanov, V. V. (1993). Ekspress-diagnostika sostoianiia derevev sosny pri podsochke. Lesnoe khoziaistvo, 3, 24-26. [In Russian].

19. Voronov, N. M. (1962). Vliiaet li podsochka na urozhainost i kachestvo semian sosny. Lesnoe khoziaistvo, 7, 80 p. [In Russian].

20. Zvarych, Yu. V. (2005). Vplyv prostorovoi struktury derevostaniv na zhyttievist derev sosny zvychainoi. Materialy 55 nauk.-tekhn. konf. profesorsko-vykladatskoho skladu, naukovykh pratsivnykiv, doktorantiv ta aspirantiv LHF NLTU Ukrainy (19-21 travnia 2005., m. Lviv) "Naukovi osnovy pidvyshchennia produktyvnosti ta biolohichnoi stiikosti lisovykh ta urbanizovanykh ekosystem". Lviv, 31-33. [In Ukrainian].

Yu. V. Zvarych', O. D. Zvarych ${ }^{2}$

${ }^{1}$ Ukrainian National Forestry University, Lviv, Ukraine ${ }^{2}$ Technological College of the Ukrainian National Forestry University, Lviv, Ukraine

\section{INFLUENCE OF TAPPING ON VITALITY, PRODUCTION AND MORPHOMETRIC INDICATORS OF SCOTS PINE SEEDS IN SMALL POLISSYA}

Studies conducted by various scientists do not provide an unambiguous conclusion about the impact of pine tree tapping on their vitality and morphometric parameters of seeds. A study of resin yield on the experimental plot for two-year term has been conducted. The results of the research have shown that average load on one pine tree with an average diameter of $37.5 \mathrm{~cm}$ was estimated to be 1.6. The average annual yield of resin per tree during the first year of tapping was determined to be almost $2.5 \mathrm{~kg}$, and during the second year of tapping it was almost $2.3 \mathrm{~kg}$. The annual dynamics of dielectric parameters at the experimental and control plots during the two years of tapping was studied. The indicator of the impedance and polarization capacity of pine trees on the experimental and control plots is found to be almost the same before tapping. At the beginning of tapping, the indicator of vitality of tapped trees is found to decrease comparing to control plots. In the second half of the seasonal tapping, the indicators of vitality begin to level off and after its completion they become almost the same on both plots. Furthermore, according to Kapper's method, the seed yield of model trees on the experimental plot was determined as medium, and on the control plot-medium-strong. The length of the cones of the samples from the experimental plots is revealed to exceed the control by $1.5-2.5 \mathrm{~mm}$. The diameter of the cones is also larger on the experimental plots by $0.9-1.2 \mathrm{~mm}$. Accordingly, the mass of cones on the experimental plots exceeds the control by $0.6-0.8 \mathrm{~g}$. The dominant shape of the cones on all experimental plots is conical. The largest indicator of seed length is observed on the experimental plot VM-9RP $(4.37 \mathrm{~mm})$, and the smallest - on the experimental plot VM-2 $(4.12 \mathrm{~mm})$. The width of the seeds is the same. Seed weight is the lowest on the experimental plot VM-2 $(5.7 \mathrm{mg})$, and the largest - on the experimental plot VM-9RP $(6.8 \mathrm{mg})$. In general, studies indicate a decrease in pine trees vitality at the beginning of the tapping season on the experimental plots and the alignment of the relevant indicators in the second half. Morphometric parameters of the cones of the experimental plots are higher than the control, and the seeds are almost the same.

Keywords: production of gum; impedance; polarization capacity; cones; seed. 